\title{
Communication
}

[Comunicação]

\section{Frequency of parasitic forms in fecal samples of maned wolf in different seasons of the year at the Serra da Canastra National Park, Minas Gerais State, Brazil}

\author{
[Frequência de formas parasitárias em massas fecais de lobos-guarás em diferentes \\ estações do ano no Parque Nacional da Serra da Canastra, $M G]$
}

\author{
D.C. Marins ${ }^{1}$, L.A. Barros $^{2 *}$, S.F. Bruno ${ }^{2}$
}

\footnotetext{
${ }^{1}$ Aluna de pós-graduação - Faculdade de Veterinária - Universidade Federal Fluminense - Niterói, RJ ${ }^{2}$ Faculdade de Veterinária - Universidade Federal Fluminense - Niterói, RJ
}

The Serra da Canastra National Park (SCNP) is located in southwestern Minas Gerais state, with an area of 200 thousand hectares, covering the municipalities of São Roque de Minas, Sacramento, Delfinópolis, São João Batista do Glória, São José do Barreiro, Capitólio, and Vargem Bonita. The SCNP is located in the Cerrado biome (scrubland) with a significant biological diversity and a rich fauna and flora, which includes numerous threatened animal species (Plano..., 2019).

Considering only mammals with a body weight equivalent to or greater than two kilos, 38 species are recognized in the SCNP, of the 46 species recognized for all Cerrado lands in the country. This gives the park great importance as a fauna conservation area, having the largest area of estimated density for maned wolves in the world, with 0.08 individual $/ \mathrm{km}^{2}$ (Paula et al., 2013).

The maned wolf (Chrysocyon brachyurus Illiger, $1815)$ is the largest canid in South America, considered near threatened by the International Union for Conservation of Nature (IUCN) and classified as endangered in the "vulnerable" degree by the official list issued by the Ministry of the Environment of Brazil (Plano..., 2019). The species is observed in Brazil from the northeast region to part of Rio Grande do Sul state, and also in Bolivia, Peru, Paraguay, Argentina, and Uruguay. In the Canastra

Recebido em 23 de fevereiro de 2021

Aceito em 18 de maio de 2021

*Autor para correspondência (corresponding author)

E-mail: lucianobarrosrj@gmail.com
Mountains they live in Cerrado scrublands and grasslands, covering areas of 20 to $30 \mathrm{~km}^{2}$ (Dietz, 1984, 1985).

Due to the fragmentation process of native Cerrado areas, these wolves came into contact with domestic species and environments, significantly increasing the likelihood of infection by numerous infectious agents, which at first were specific to domestic animals, including gastrointestinal parasites (Braga et al., 2010; Curi et al., 2010, 2012; Santos et al., 2012; Paula et al., 2013).

Parasitic infections can occur in different age groups, but it is more severe in canine puppies under the age of six months. Enteritis, anorexia, anemia, ataxia, blood and/or mucus in stool, and weight loss are the most frequent clinical signs (Wallach and Boever, 1983). Although gastrointestinal parasites are the primary cause of weakness and natural death in maned wolves, studies on the parasitofauna of this species are still rare, and the diagnosis has generally been made by coproparasitological tests, which allow the taxonomic identification of evolutionary forms like eggs, cysts and larvae found in feces. However, because of the lack of morphological data, they do not always clarify the species of the agents involved (Dietz, 1984; Mundim et al., 1991).

The study of the parasitofauna of wild species in natural environments like the maned wolf is of key importance for the evaluation of the parasite 
transmission flow between domestic and wild animals. It also allows to assess the impact chains of anthropic action on natural ecosystems (Brandão et al., 2009).

During the period from March 2017 to November 2019, 103 samples of fresh feces were collected from the SCNP grounds. The collection points were situated in the section closest to the urban area of São Roque de Minas, Minas Gerais state, located at $20^{\circ} 15.521^{\prime}$ south latitude and $46^{\circ} 24.140^{\prime}$ west longitude. To minimize the risk of sample contamination by environmental agents, only the most aerial portion of the scats were used.

The geolocation of the collection points was performed for each sample, using a GPS (Global Position System) device. In addition, the ethological characteristics of the host were observed, such as: spot chosen to defecate, footprints in the circumjacent area and presence of traces of the diet in the scats.

All samples were kept in sterile plastic flasks with screw cap, duly identified and containing preservative liquid (70\% ethyl alcohol) in an amount of at least twice the sample volume. The samples were transported to the Laboratory of Diagnostic Support in Parasitic Diseases of Federal Fluminense University for processing and analysis.

At the laboratory samples were processed by centrifugal flotation methods in a saturated sucrose solution (Sheather technique) and by spontaneous sedimentation technique (HPJ technique). Readings were obtained from three slides of each processed sample. The diagnosis of parasitic structures was performed under optical microscopy according to Soulsby (1982), Gilioli and Silva (2000), and Massara et al. (2015). The term frequency was used according to Bush et al. (1997).

At least one species of parasite was detected in 47 samples $(45.63 \%)$, of which $34(33 \%)$ with only one species of parasite; $11(10.67 \%)$ with two species; one $(0.97 \%)$ with three species; and one $(0.97 \%)$ with four species. The season with the highest frequency of positive samples was autumn, with $60.86 \%$ (14/23), followed by winter, with $52.38 \%(11 / 21)$; summer, with $37.5 \%$ (15/40); and spring, with $36.84 \%$ (7/19).

Among the parasitic forms detected, Capillaria sp. eggs were the most frequent, being found in 23 samples $(22.33 \%)$, followed by trematode eggs in 15 samples (14.56\%); eggs of acanthocephalans, ascarids, Trichuris sp. and Ancylostoma sp. in five samples (4.85\%); superfamily Strongyloidea eggs and Lynxacarus sp. (adults and eggs) in two samples (1.94\%); and pentastomid eggs in one sample $(0.97 \%)$, as shown in Fig.1.

Of the positive samples collected in summer, $46.7 \%$ (7/15) were infected with Capillaria sp.; $26.7 \%$ (4/15) with Ancylostoma sp.; $13.4 \%$ (2/15) with Trichuris sp., Lynxacarus sp., trematodes (Class Trematoda) and acanthocephalans (Phylum Acantocephala); and $6.7 \% \quad(1 / 15) \quad$ with pentastomids (sC Pentastomide) and ascarids (Sf Ascaroidea).

Of the positive samples collected in spring, $42.9 \%$ (3/7) were infected with Capillaria sp. and trematodes; $14.3 \%$ (1/7) with Ancylostoma sp., acanthocephalans, Trichuris sp. and strongyles (Sf Strongyloidea).

Of the positive samples collected in winter, $36.36 \%$ (4/11) were infected with Capillaria sp.; $27.27 \%(3 / 11)$ with trematodes and ascarids; $18.18 \%$ (2/11) with acanthocephalans; and 9.09\% (1/11) with Trichuris sp.

Of the positive samples collected in autumn, $64.28 \%$ (9/14) were infected with Capillaria sp.; $50 \%$ (7/14) with trematodes; $7.14 \%$ (1/14) with Trichuris sp., ascarids and strongyles. (Table 1).

The fragmentation process of native areas in the Cerrado allows populations of wild carnivores, when living in impacted areas, to get to domestic environments. Likewise, domestic species like dogs may be encountered in natural areas, interfering with the biological dynamics of wild communities and facilitating the sharing of agents responsible for diseases in these animals (Hughes and MacDonald, 2013; Paula et al., 2013). 

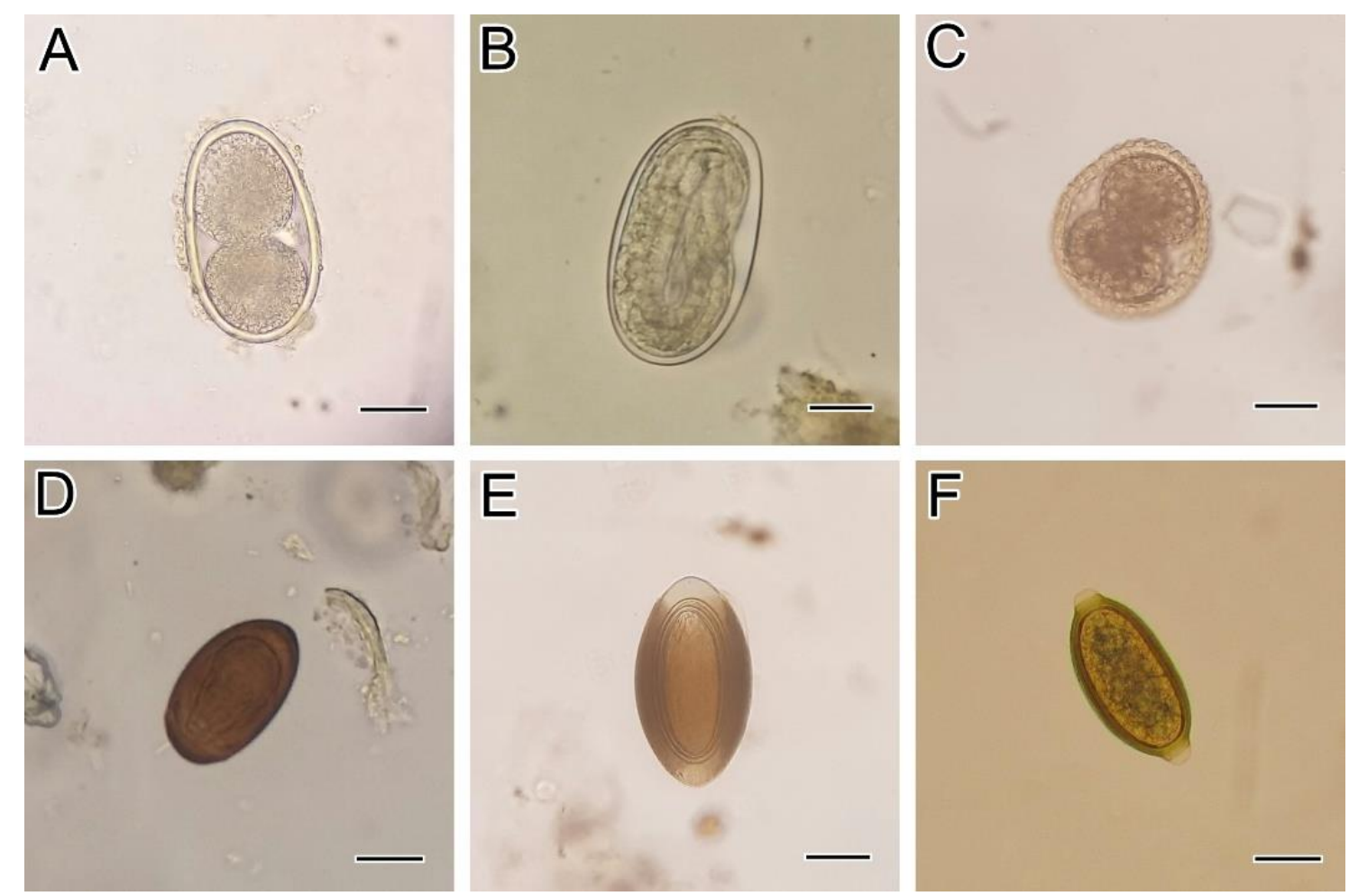

Figure 1. Eggs of endoparasites found in coproparasitological tests of maned wolves (Chrysocyon brachyurus) from the Serra da Canastra National Park, Minas Gerais state. (A) Superfamily Ascaroidea, bar $=20 \mu \mathrm{m}$, (B) Ancylostoma sp., bar $=20 \mu \mathrm{m}$, (C) Superfamily Ascaroidea, (D) Class Trematoda, bar $=$ $20 \mu \mathrm{m}$, (E) Phylum Acantocephala, bar $=20 \mu \mathrm{m}$, (F) Capillaria sp., bar $=20 \mu \mathrm{m}$.

Table 1. Parasites found in feces of maned wolves (Chrysocyon brachyurus), collected in the Serra da Canastra National Park area, Minas Gerais state, in different climatic seasons from March 2017 to November 2019.

\begin{tabular}{|c|c|c|c|}
\hline $\begin{array}{c}\text { Climatic } \\
\text { season /year }\end{array}$ & Parasites & $\begin{array}{c}\text { Number of } \\
\text { samples } \\
\text { tested }\end{array}$ & $\begin{array}{l}\text { Number of } \\
\text { positive } \\
\text { samples }\end{array}$ \\
\hline Summer/2017 & $\begin{array}{l}\text { Acanthocephalans, Ancylostoma sp., trematodes, Trichuris } \\
\text { sp. }\end{array}$ & 9 & 6 \\
\hline Autumn/2017 & Acanthocephalans, Capillaria sp., strongyles & 6 & 4 \\
\hline Spring/2017 & $\begin{array}{l}\text { Ancylostoma sp.; Capillaria sp., strongyles, trematodes, } \\
\text { Trichuris sp. }\end{array}$ & 17 & 5 \\
\hline Summer /2018 & $\begin{array}{l}\text { Ancylostoma sp., Capillaria sp., Lynxacarus sp., } \\
\text { pentastomids, ascarids, trematodes }\end{array}$ & 31 & 9 \\
\hline Autumn/2018 & Capillaria sp., ascarids, trematodes, Trichuris sp., strongyles & 17 & 10 \\
\hline Winter/2018 & $\begin{array}{l}\text { Acanthocephalans, Capillaria sp., ascarids, trematodes, } \\
\text { Trichuris sp. }\end{array}$ & 11 & 8 \\
\hline Spring/2018 & Capillaria sp., Acanthocephalans & 2 & 2 \\
\hline Winter/2019 & Capillaria sp., ascarids & 10 & 3 \\
\hline Total & & 103 & 47 \\
\hline
\end{tabular}

Some parasites like Ancylostoma sp., ascarids and capillarids have also been found in studies of maned wolf's feces, with a likely origin in domestic canids. In these cases, there is also the possibility of transmission to humans, which characterizes the zoonotic importance of these species (Mirdha et al., 1998; Gilioli and Silva, 2000; Brandão et al., 2009; Massara et al., 2015). Eggs of both Ancylostoma sp. and capillarids were found in the SCNP fecal samples, and Capillaria sp. was the most frequent parasite in all seasons. 
Massara et al. (2015) performed coproparasitological tests in fecal samples of maned wolves in the Cerrado area of Serra da Calçada, in Belo Horizonte, Minas Gerais state. Although results are compatible with those of the SCNP study, those authors found higher parasitism rates, mainly for acanthocephalans $(80.9 \%)$, followed by capillarids $(78.5 \%)$ and ancylostomatidae $(35.7 \%)$. This difference is probably due to the greater anthropic action and easier contact with domestic animals that affect maned wolves in the study area of Serra da Calçada.

Trichurid eggs were equally found by Gilioli and Silva (2000) in scats of maned wolves kept in zoos in São Paulo. These parasites are easily found in domestic canids (Leite et al., 2004). There are also records of infection by $T$. vulpis in humans (Mirdha et al., 1998), which emphasizes the zoonotic character of this nematode.

Brandão et al. (2009) infer that the greatest diversities of helminthological fauna are related to host species whose diets are broad and opportunistic, as in the case of $C$. brachyurus. Besides, anthropized borders can become attractive because of the abundance of some resources present there, regardless of the climatic season. Therefore, it is necessary to sample regions of the SCNP not included in this study, especially the park bordering areas, for a more comprehensive knowledge of the parasitic fauna of maned wolf populations.

The presence of a high rate of intestinal parasites, combined with factors such as fragmentation of areas, hunting and scarcity of food resources, can pose a threat to populations already at risk, like the $C$. brachyurus (Braga et al., 2010).

The study results indicate that different parasitic cycles are occurring in the SCNP and that maned wolves act as definitive hosts for several species of parasites. The presence of trematodes, pentastomids and acanthocephalans in fecal samples demonstrates that maned wolves participate as predators in food chains, in which mollusks, insects, ophidians, rodents, lacertilians and batrachians are also found, as these organisms act as paratenic or intermediate hosts of the identified parasites.

Although high-frequency values were found for some forms of gastrointestinal parasites, no signs of clinical changes like vomiting, diarrhea, presence of blood in the stool, or death were observed at the collection points during the study period.

The adoption of parasite control measures in the bordering areas of the Serra da Canastra National Park, in particular of gastrointestinal parasites that affect domestic canids, is important to minimize the transmission flow between domestic canids and wolves. This type of monitoring requires a multidisciplinary approach, but the data already collected can be used to assist in conservation actions targeting populations of threatened species like the maned wolf.

Keywords: Canidae; Parasitosis;

Coproparasitological diagnosis; Conservation

\section{RESUMO}

O Parque Nacional da Serra da Canastra (PNSC), localizado no estado de Minas Gerais, é um importante habitat de inúmeras espécies de animais ameaçados de extinção, como o lobo-guará (Chrysocyon brachyurus). Parasitos de animais selvagens podem representar um problema para os programas de manejo e recuperação de espécies ameaçadas, pois atuam como causa primária ou agravante de inúmeras doenças. Dependendo da época do ano, a suscetibilidade ao parasitismo pode ser maior devido à facilidade de infecção. Com o objetivo de avaliar a frequência de endoparasitos e a sazonalidade dessas parasitoses em diferentes épocas do ano, foram examinadas 103 amostras fecais de lobos-guarás, coletadas no PNSC, durante o período de março de 2017 a agosto de 2019. O número de amostras positivas para pelo menos uma espécie de parasito foi de 47 amostras (45,63\%), sendo o outono a estação em que foi encontrada a maior frequência de formas parasitárias, com 60,86\% (14/23) de amostras positivas, seguido do inverno, com 52,38\% (11/21), verão com 37,5\% (15/40), e primavera com 36,84\% (7/19). Dentre os parasitos encontrados, Capillaria sp. apresentou a maior frequência, sendo encontrado em 23 amostras (22,33\%), seguido de trematódeos, em 15 amostras (14,56\%), acantocéfalos, ascarídeos, Trichuris sp. e Ancylostoma sp., em cinco amostras (4,85\%), nematoides da 
superfamília Strongyloidea, Lynxacarus sp., em duas amostras (1,94\%), e pentastomídeos em uma amostra $(0,97 \%)$.

Palavras-chave: Canidae, parasitoses, diagnóstico coproparasitológico, conservação

\section{REFERENCES}

BRAGA, R.T.; VYNNE, C.; LOYOLA, R.D. Fauna parasitária intestinal de Chrysocyon brachyurus (lobo-guará) no Parque Nacional das Emas. Bioikos, v.24, p.49-55, 2010.

BRANDÃO, M.L.; CHAME, M.; CORDEIRO, J.L.P.; CHAVES, S.A.M. Diversidade de helmintos intestinais em mamíferos silvestres e domésticos na caatinga do Parque Nacional da Serra da Capivara, sudeste do Piauí, Brasil. Rev. Bras. Parasitol. Vet., v.18, p.19-28, 2009.

BUSH, A.O.; LAFFERTY, K.D.; LOTZ, J.M.; SHOSTAK, A.W. Parasitology meets ecology on its own terms: Margolis et al. revisited. J. Parasitol., v.63, p.575-583, 1997.

CURI, N.H.A.; ARAÚJO, A.S.; CAMPOS, F.S. et al. Wild canids, domestic dogs and their pathogens in Southeast Brazil: disease threats for canid conservation. Biodiversity Conserv., v.19, p.3513-3524, 2010.

CURI, N.H.A.; COELHO, C.M.; MALTA, M.D.C.C. et al. Pathogens of wild maned wolves (Chrysocyon brachyurus) in Brazil. J. Wildlife Diseases, v.48, p.1052-1056, 2012.

DIETZ, J.M. Chrysocyon brachyurus maned wolf. Mamm. Species, v.23, p.1-4, 1985.

DIETZ, J.M. Ecology and social organization of the maned wolf Chrysocyon brachyurus. Smithsonian Contrib. Zool., v.1, p.1-51, 1984.

GILIOLI, R.; SILVA, F.A. Frequência de parasitas e infecção por salmonella em lobos guará, Chrysocyon brachyurus, mantidos em zoológicos no Estado de São Paulo. Arq. Bras. Med. Vet. Zootec., v.52, p.337-341, 2000.

HUGHES, J.; MACDONALD, D.W. A review of the interactions between free-roaming domestic dogs and wildlife. Biol. Conserv., v.157, p.341-351, 2013.
PLANO DE AÇÃO NACIONAL PARA A CONSERVAÇÃO DOS CANÍDEOS. Brasília: ICMbio, 2019. Available in: https://www.icmbio.gov.br. Accessed in: 14 Jan. 2019.

LEITE, L.C.; MARINONI, L.P.; CÍRIO, S.M. et al. Endoparasitas em cães (Canis familiaris) na cidade de Curitiba - Paraná - Brasil. Arch. Vet. Sci., v.9, p.95-99, 2004.

MASSARA, R.L.; PASCHOAL, A.M.O.; CHIARELLO, A.G. Gastrointestinal parasites of maned wolf (Chrysocyon brachyurus, Illiger, 1815) in a suburban area in southeastern Brazil. Braz. J. Biol., v.75, p.643, 2015.

MIRDHA, B.R.; SINGH, Y.G.; SAMANTRAY, J.C. et al. . Trichuris vulpis infection in slum children. Indian J. Gastroenterol., v.17, p.154, 1998.

MUNDIM, M.J.S.; MACHADO, M.I.; BEVILAQUA, E. et al. Ocorrência e identificação de ancilostomatídeos em loboguará Chrysocyon brachyurus (Illiger, 1811) da região do Triângulo Mineiro, Minas Gerais, Brasil. Braz. J. Vet. Res. Anim. Sci., v.28, p.39, 1991.

PAULA, R.C.; RODRIGUES, F.H.G.; QUEIROLO, D. et al. Avaliação do estado de conservação do lobo-guará (Chrysocyon brachyurus) no Brasil. Rev. Biodivers. Bras., v.3, p.146-159, 2013.

SANTOS, J.L.; MAGALHÃES, N.B.; SANTOS, H.A. et al. Parasites of domestic and wild canids in the region of Serra do Cipó National Park, Brazil. Rev. Bras. Parasitol. Vet., v.21, p.270277, 2012.

SOULSBY, E.J.L. Helminths, arthropods \& protozoa of domesticated animals. 7.ed. London: Lea \& Febiger, 1982. 824p.

WALLACH, J.D.; BOEVER, W.J. Diseases of exotic animals: medical and surgical management. London: W.B. Saunders, 1983. 1159 p. 